\title{
Human Neutrophil Elastase Activated Fluorescent Probe for Pulmonary Diseases Based on Fluorescence Resonance Energy Transfer Using CdSe/ZnS Quantum Dots
}

Shi-Yu Liu, ${ }^{\dagger, \S}$ Ai-Min Yan, ${ }^{\dagger} \S \mathrm{Wu}$ Ying-Zheng Guo, ${ }^{\dagger}$ Yuan-Yuan Fang,, Qing-Jian Dong, ${ }^{\ddagger}$ Rong-Rong Li,${ }^{\dagger}$ Sheng-Nan Ni, ${ }^{\dagger}$ Yao Sun,${ }^{\dagger}$ Wen-Chao Yang,,${ }^{*} \dagger$ and Guang-Fu Yang ${ }^{*} \dagger$, I

†ey Laboratory of Pesticide \& Chemical Biology of Ministry of Education, International Joint Research Center for Intelligent Biosensor Technology and Health, and Chemical Biology Center, College of Chemistry, Central China Normal University, Wuhan 430079, P.R. China;

†ongji Hospital of Tongji Medical College, Huazhong University of Science and Technology, Wuhan 430074, P.R. China;

'Collaborative Innovation Center of Chemical Science and Engineering, Tianjin 30071, P.R. China.

\footnotetext{
$\S$ These two authors made equal contributions.

*Wen-Chao Yang, e-mail: tomyang@mail.ccnu.edu.cn; Tel: 86-27-67867706; Fax: 86-2767867141; Guang-Fu Yang, e-mail: gfyang@ mail.ccnu.edu.cn; Tel: 86-27-67867800; Fax: 86-27-67867141.
} 

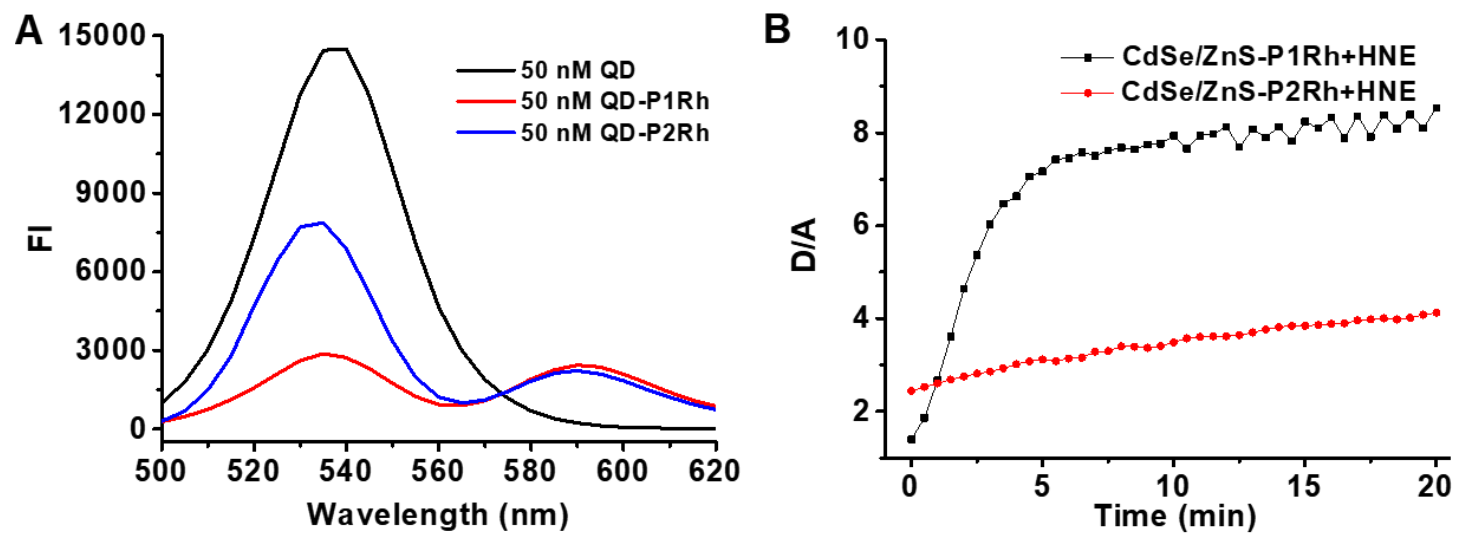

Figure S1. (A) The fluorescence spectra of CdSe/ZnS QDs (50 nM) in Tris-HCl buffer (100 mM, pH 7.5) before and after conjugated to sulfo-Rhodamine B labeled peptide $\mathbf{P 1}$ and P2. (B) The proteolysis efficiency of CdSe/ZnS-P1 and CdSe/ZnS-P2 complex by $0.1 \mu \mathrm{g} / \mathrm{mL} \mathrm{HNE}$ in Tris-HCl buffer (100 mM, pH 7.5).
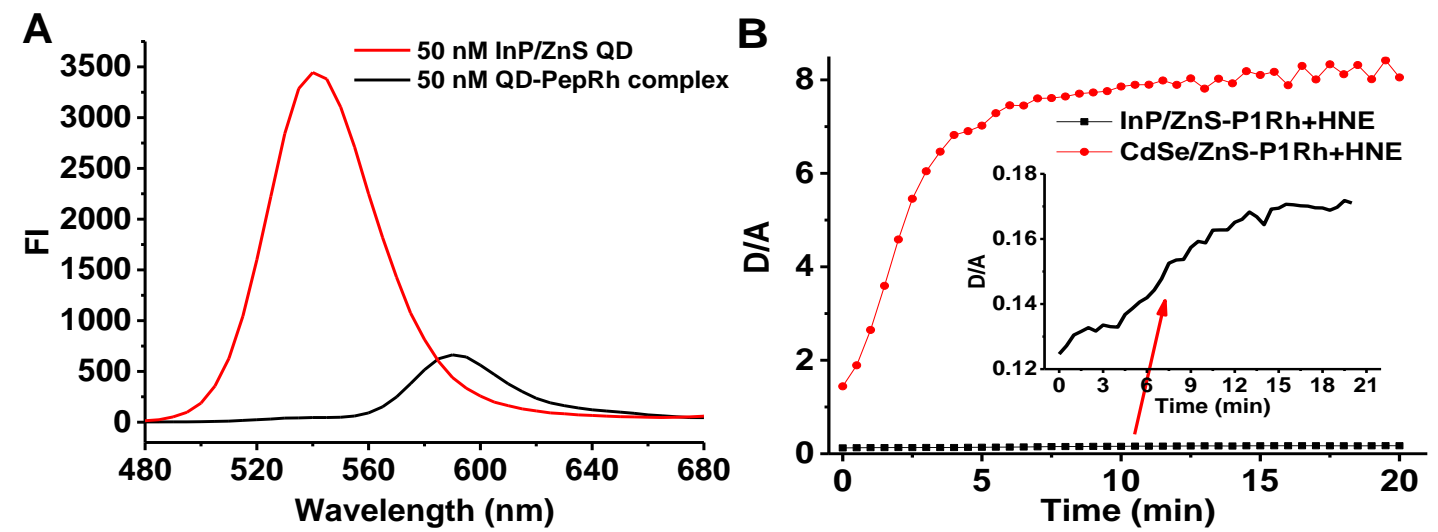

Figure S2. (A) The fluorescence spectra of InP/ZnS QDs (50 nM) in Tris-HCl buffer (100 mM, pH 7.5) before and after conjugated to sulfo-Rhodamine B labeled peptide P1. (B) The time-dependent proteolysis efficiency of InP/ZnS-P1 and CdSe/ZnS-P1 complex by $0.1 \mu \mathrm{g} / \mathrm{mL}$ HNE in Tris-HCl buffer (100 mM, pH 7.5). 

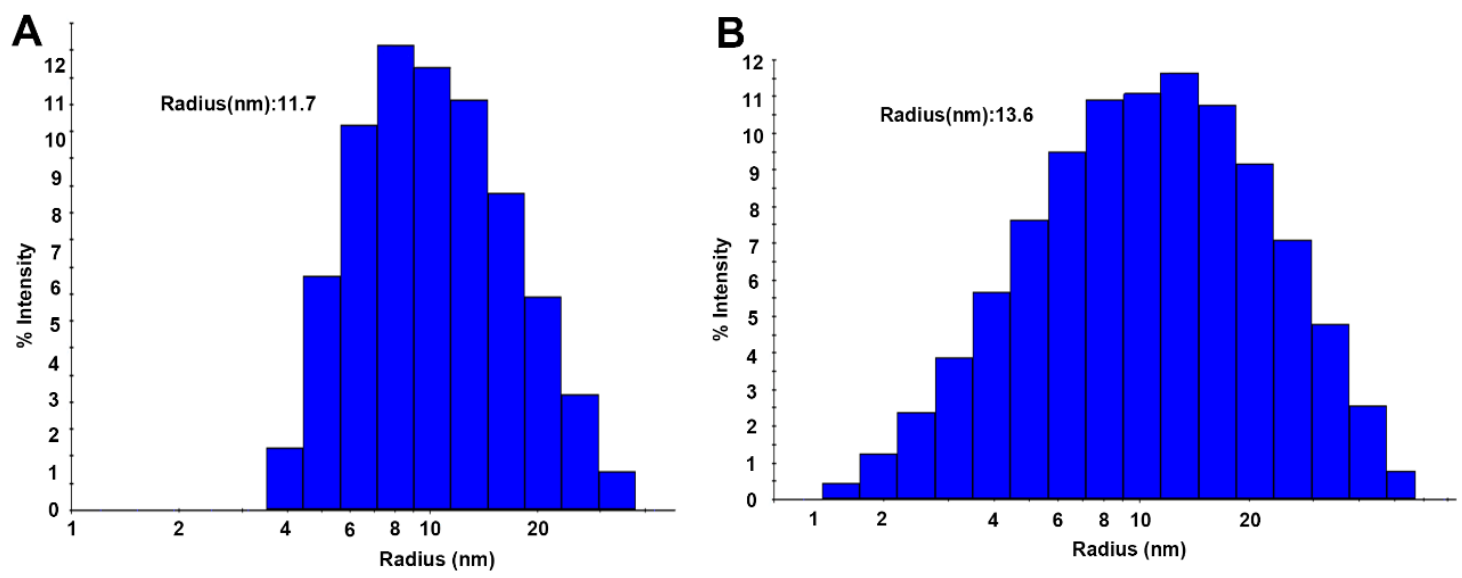

Figure S3. Size distribution of QDs before (A) and after (B) conjugation of dye-labeled peptide determined by Dynamic Light Scattering. It was observed that the radius of the QDs particle sizes increased from $11.7 \pm 0.4 \mathrm{~nm}$ to $13.6 \pm 0.6 \mathrm{~nm}$ after the conjugation.

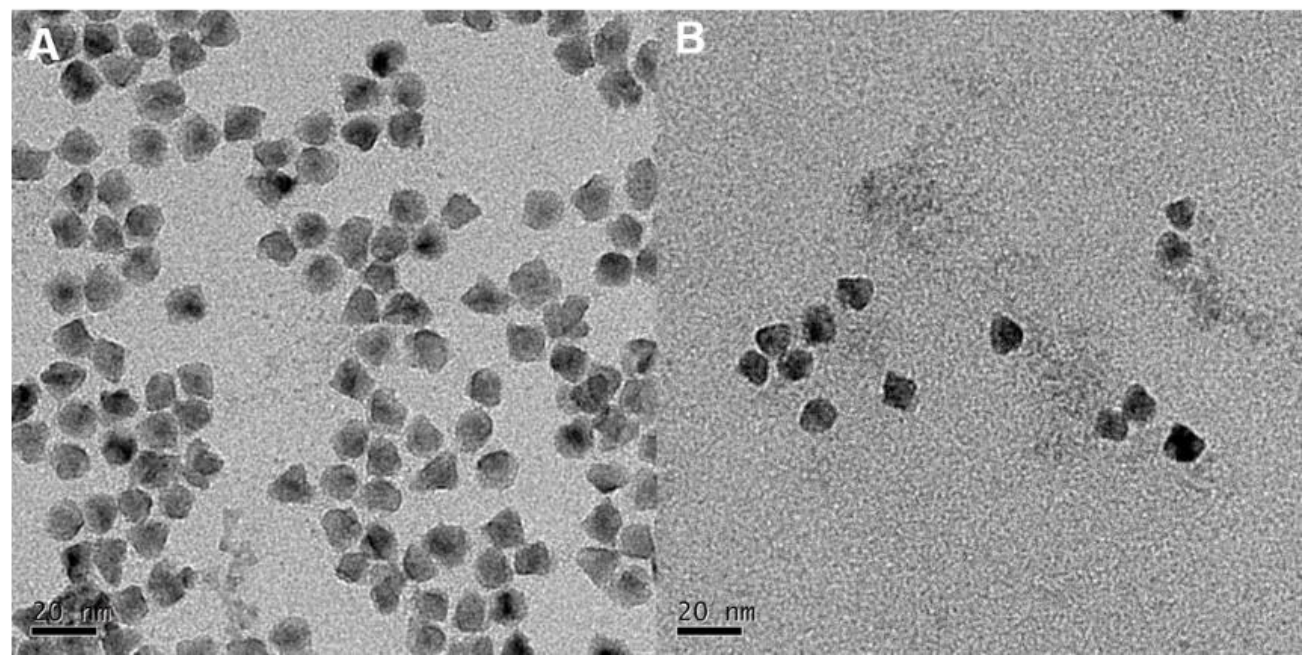

Figure S4. TEM imaging of QD (A) and QDP (B) in Tris- $\mathrm{HCl}(100 \mathrm{mM}, \mathrm{pH}=7.5)$. 


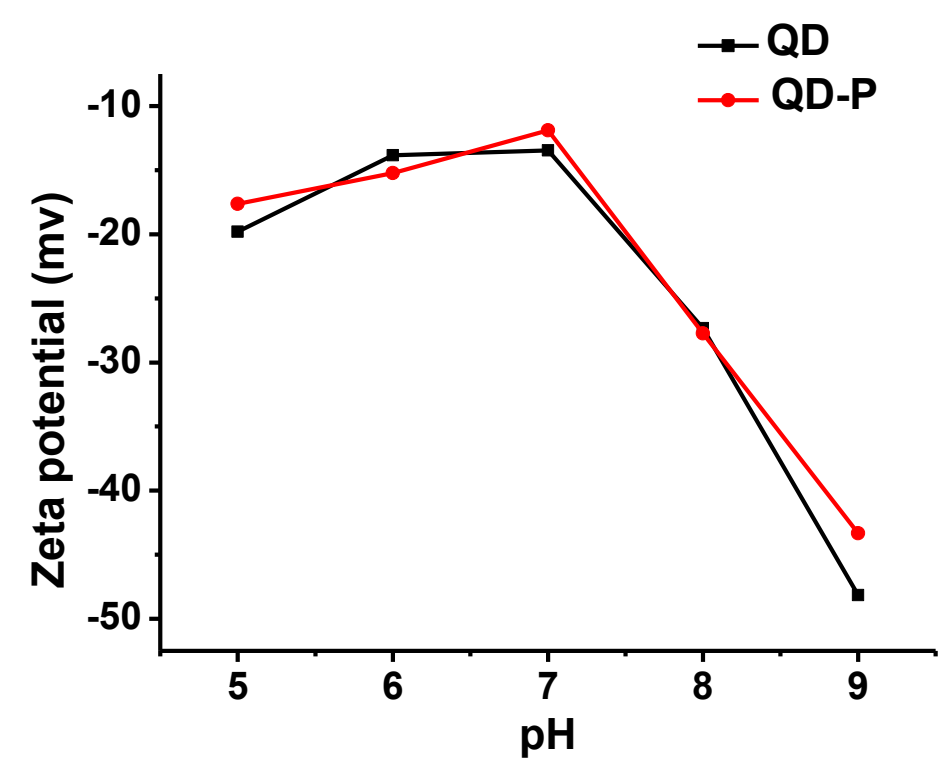

Figure S5. Determination of zeta potential for QDP by Malvern Nano-ZS90 in a series of $\mathrm{pH}(\mathrm{pH}=5 \sim 9)$ at $25^{\circ} \mathrm{C}$.

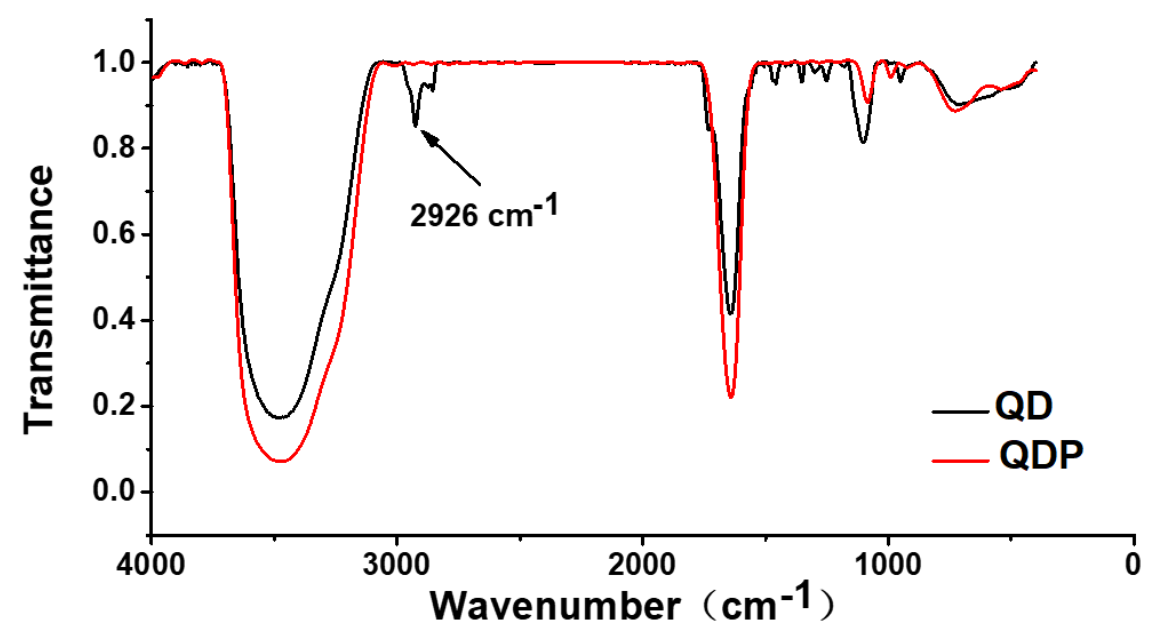

Figure S6. The FTIR spectra of QD and QDP obtained from Bruker Tensor 27 infrared spectrometer. Samples were prepared by the KBr pressed-disk technique. 


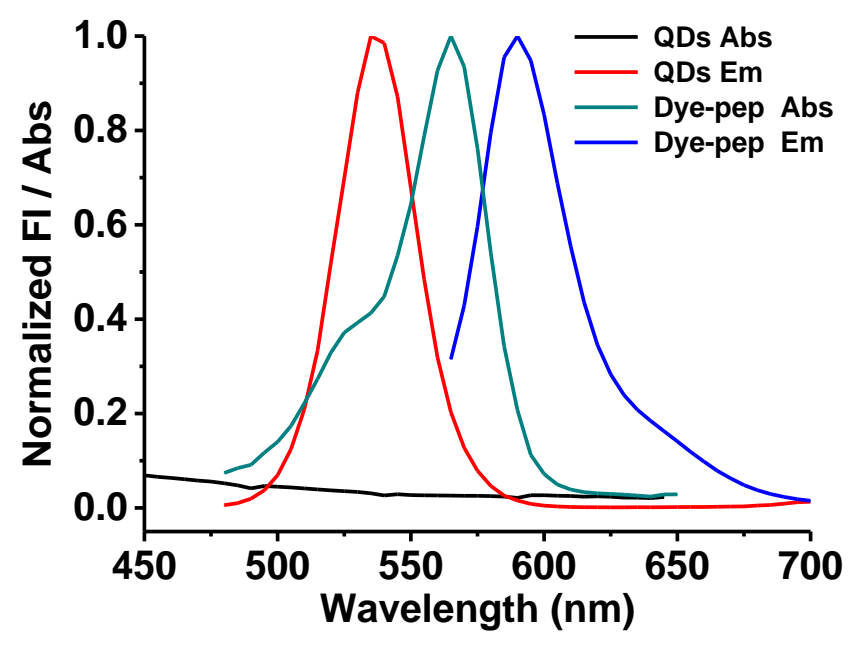

Figure S7. Normalized absorption and emission spectra for the $540 \mathrm{~nm}$ emitting QDs and sulforhodamine B labeled peptide.
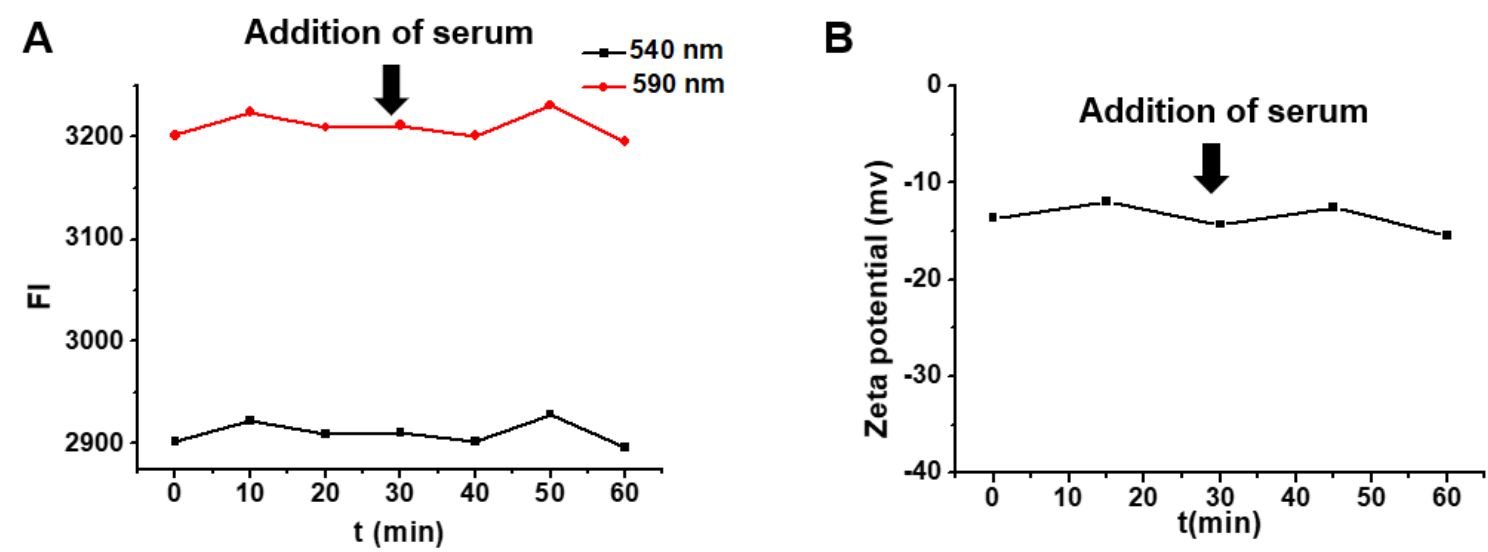

Figure S8. Stability of QDP in Tris-HCl buffer ( $\mathrm{pH}$ 7.5) with or without serum, which was monitored by fluorescence change (A) and zeta potential change (B) up to $60 \mathrm{~min}$. 


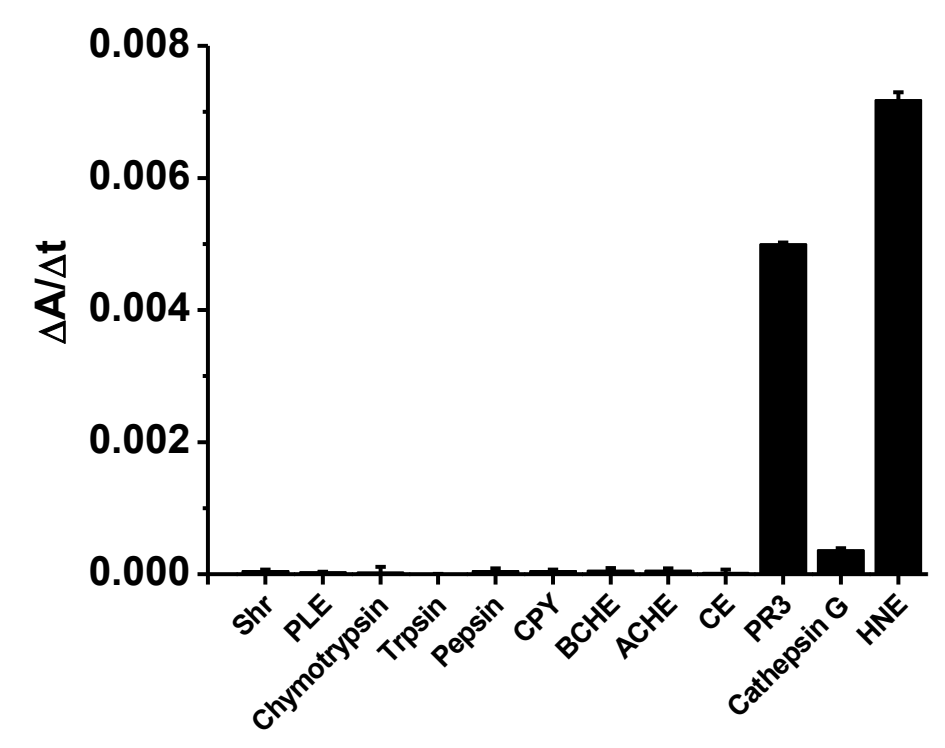

Figure S9. The specificity profile of MeOSuc-AAPV-pNA $(10 \mu \mathrm{M})$ toward different enzyme in Tris- $\mathrm{HCl}$ buffer $(0.1 \mu \mathrm{g} / \mathrm{mL} \mathrm{HNE}$ and $1 \mu \mathrm{g} / \mathrm{mL}$ PLE, chymotrypsin, trypsin, CPY, BChE, AChE, CE, PR3 and CPG in Tris-HCl buffer (100 mM, pH 7.5), $1 \mu \mathrm{g} / \mathrm{mL}$ pepsin at $\mathrm{pH}=2.0)$. Shr refers to the rate of spontaneous hydrolysis rate.

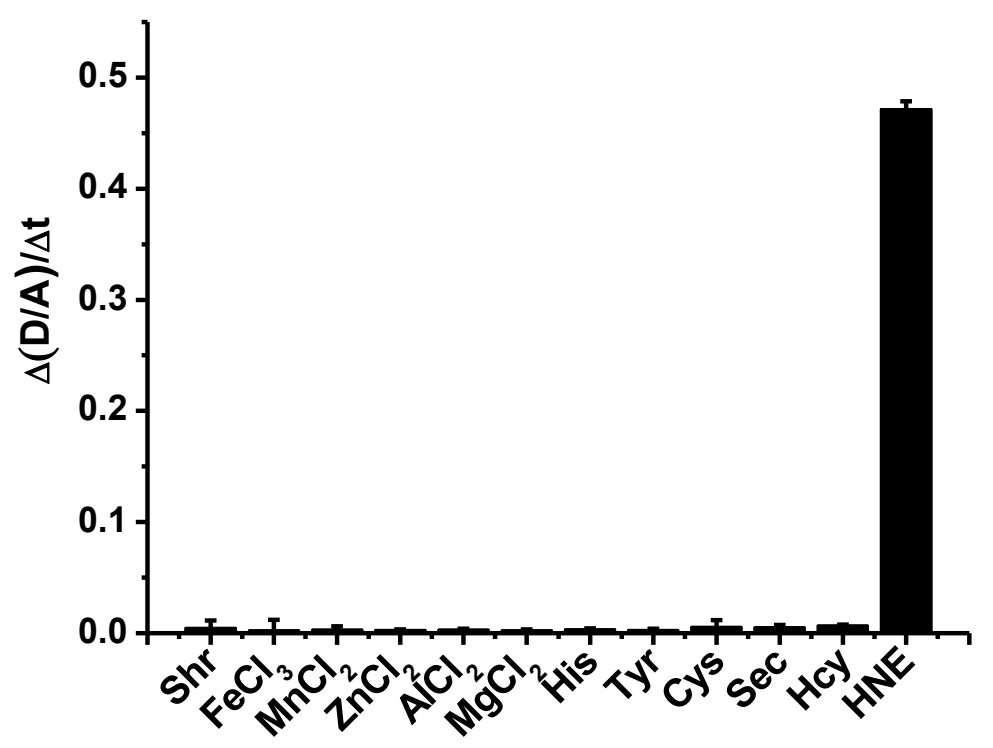

Figure S10. The specificity profile of QDP $(10 \mathrm{nM})$ toward different metal ions, amino acids and bio-active thiols $(100 \mathrm{mM})$. Shr refers to the rate of spontaneous hydrolysis rate. Sec and Hcy refer to the selenocysteine and homocysteine, respectively. 

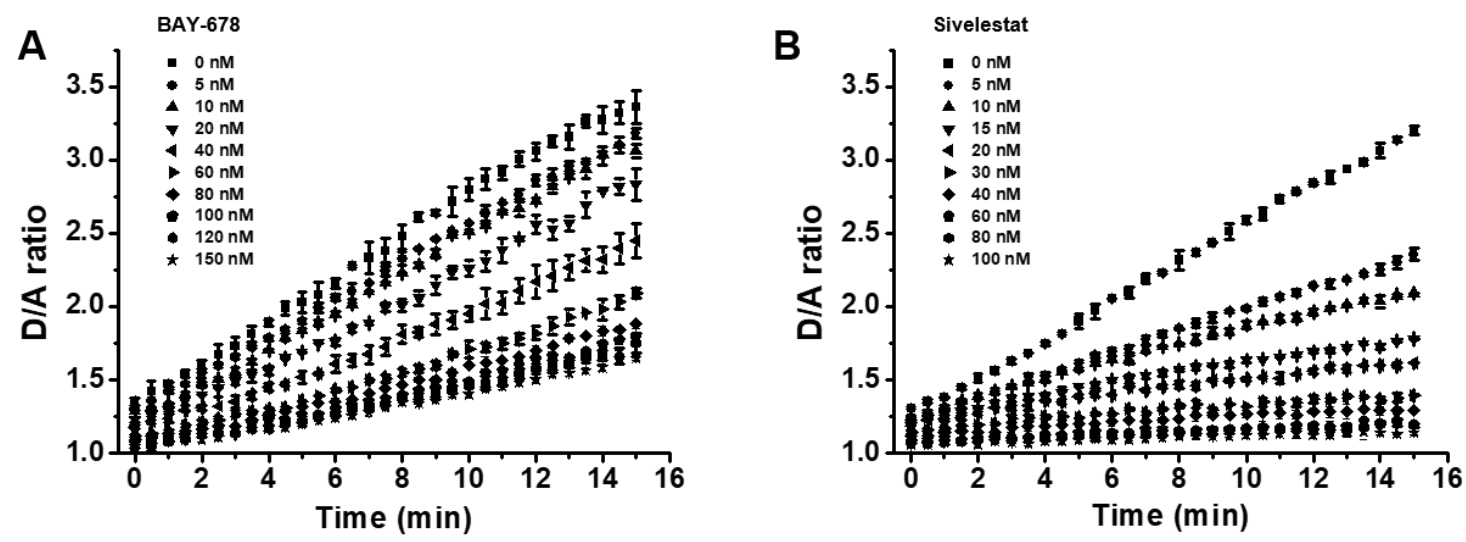

Figure S11. Time dependent inhibition of HNE by BAY-678 (A) and sivelestat (B) using QDP as the substrate. In each concentration the experiment was repeated for 3 times and the D/A ratio change per minutes was used for measurement of HNE activity.

Bright Field Green Channel Red Channel Merge

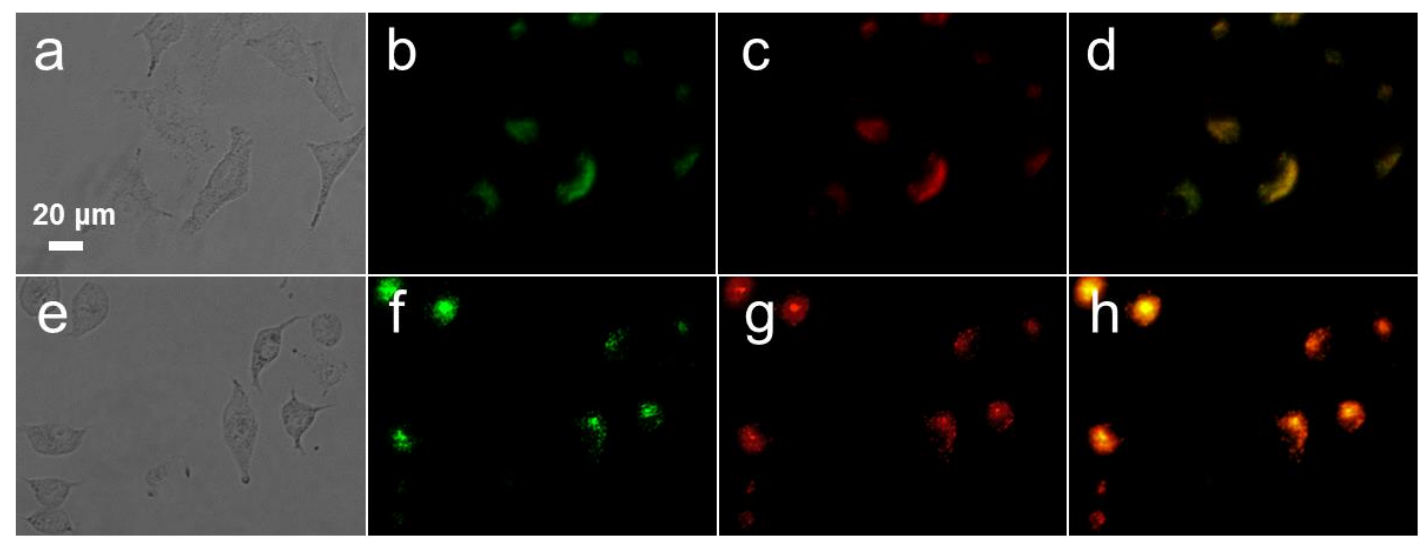

Figure S12. (a-d) Colocalization of dye-labeled peptide and green lysosome dye and in A549 cells. (e)-(h) Colocalization of QDs and red lysosome dye in A549 cells. 
A

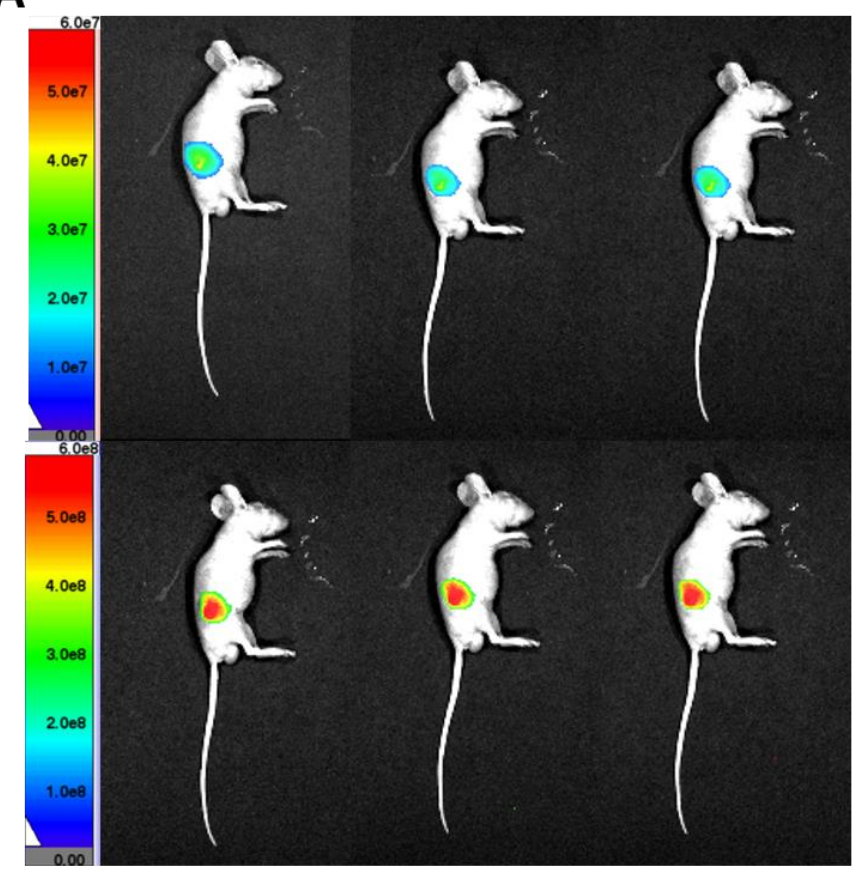

B

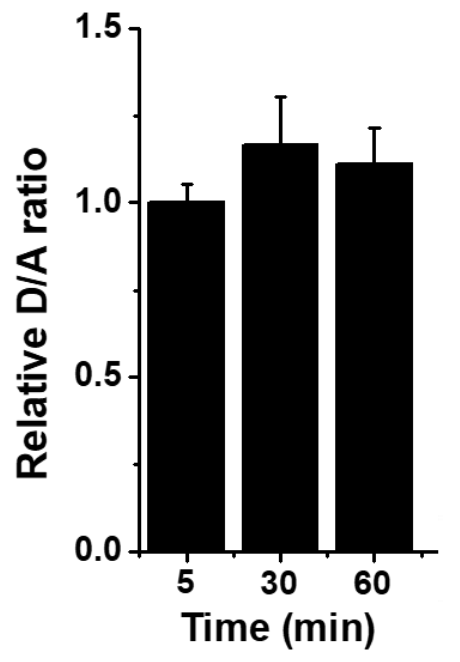

Figure S13. (A) Fluorescence image taken form nude mice ( $n \geqq 3)$ after injection with QDP in situ at various time points (5, 30,60 min). (B) Quantitively determination of fluorescence signal change of the left panel using $\mathrm{D} / \mathrm{A}$ ratio change.
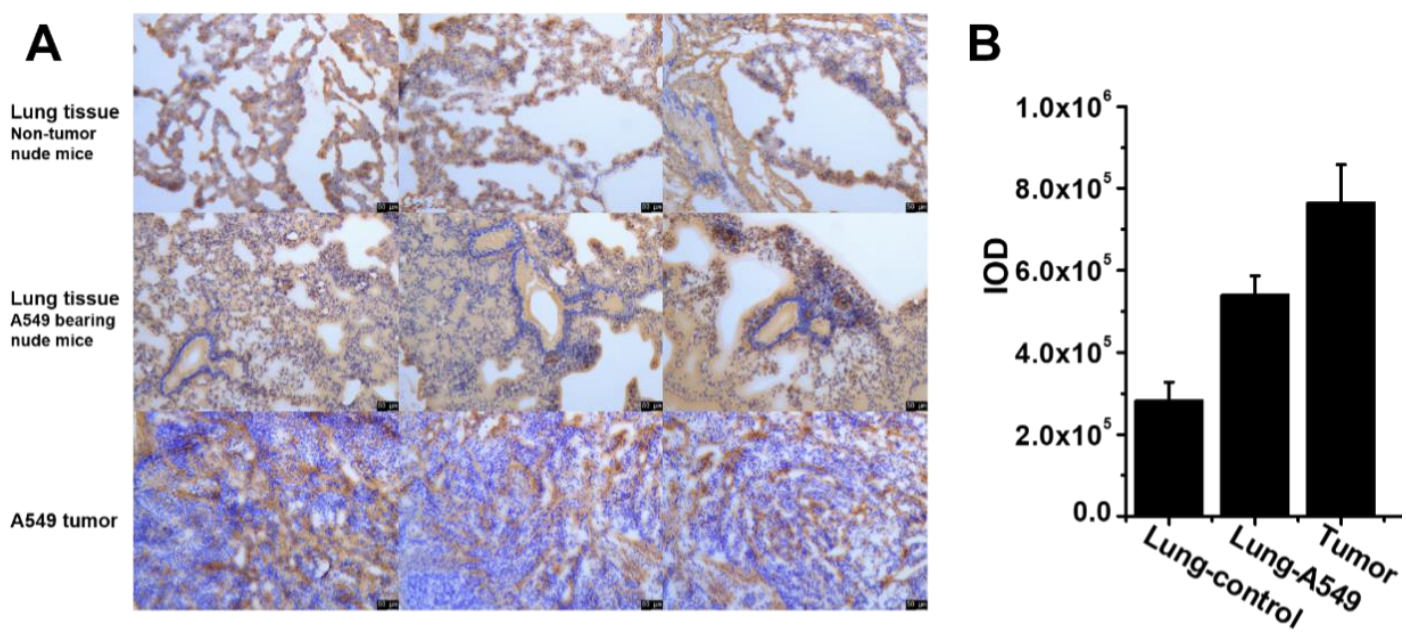

Figure S14. (A) Immunohistochemistry analysis of expression of HNE in lung tissues of non-tumor mice (up panel), adjacent non-cancerous tissues (bottom panel) of A549 bearing mice and cancerous tissues (middle panel). (B) The corresponding quantification results of average integrated optical density (IOD) of each group of A. 

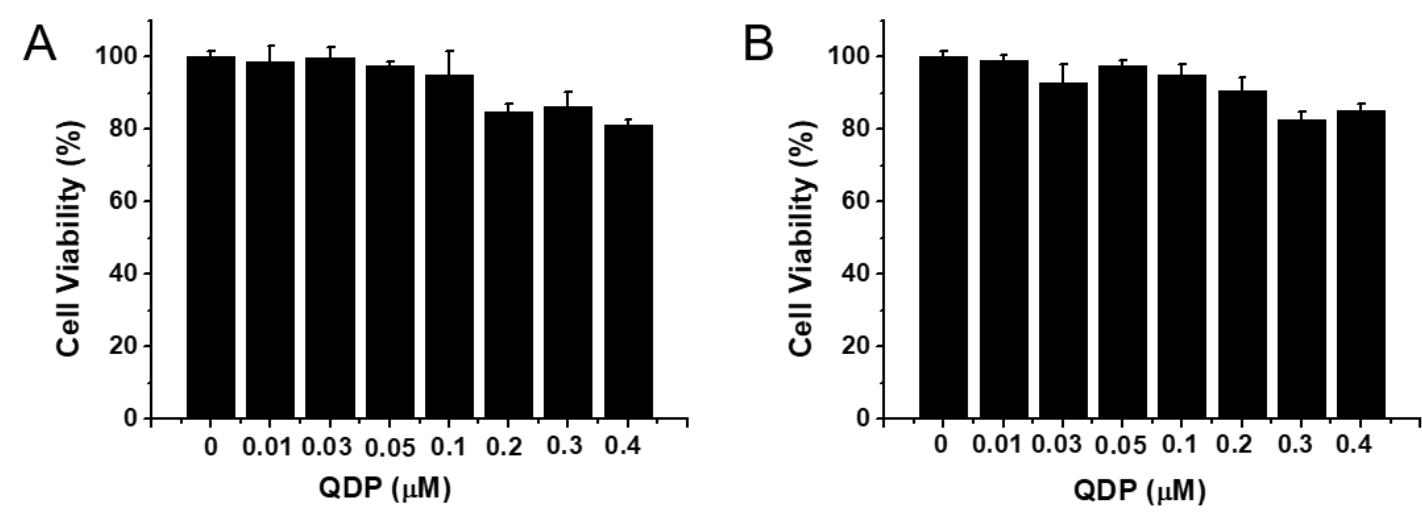

Figure S15. Determination of cytotoxicity of QDP against RBL-2H3 cells (A) and A549 cells (B) by MTT assay.

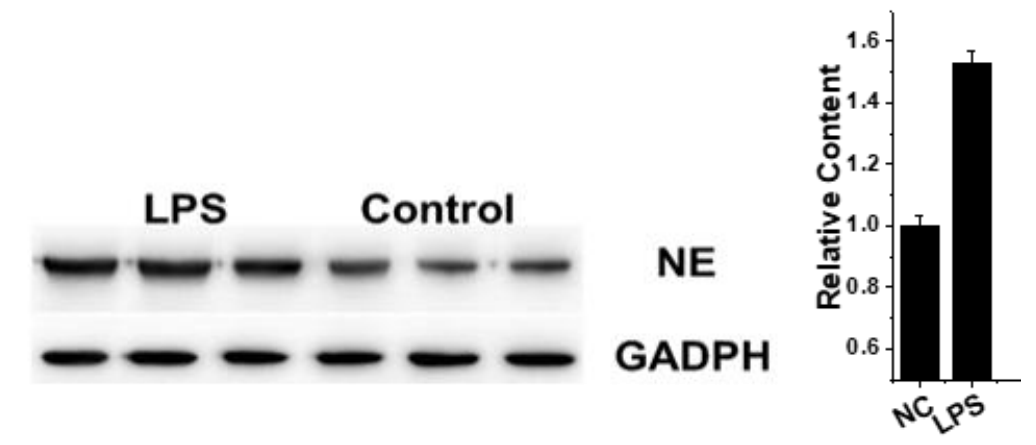

Figure S16. Western blot analysis of HNE expression in RBL-2H3 cells with (left three bands) or without (right three bands) the stimulation by LPS, the corresponding quantitative analysis was listed in the right panel. 

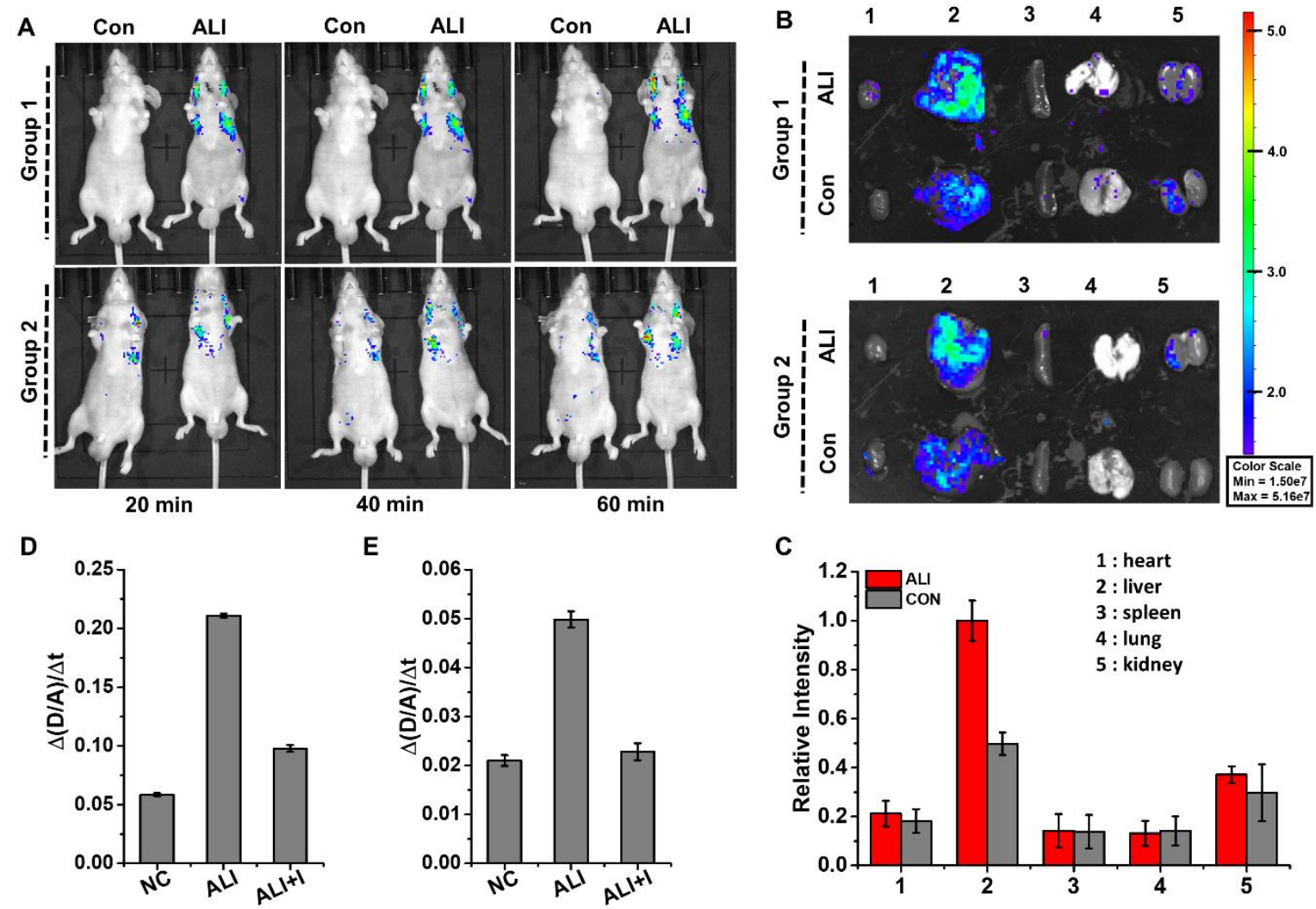

E

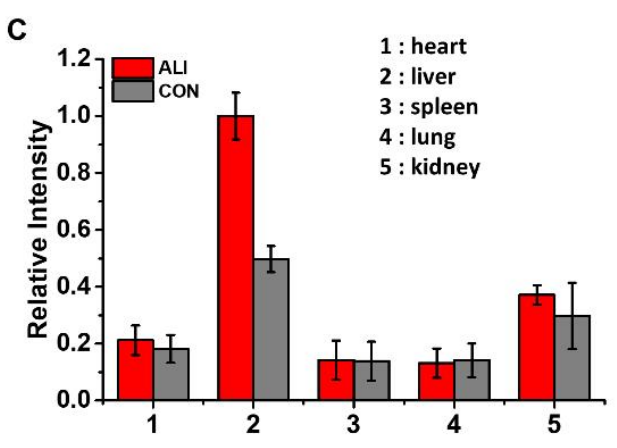

Figure S17. In Vivo imaging with QDP in acute lung injury (ALI) model BLAB/c mice.

(A) Fluorescence image taken from control or ALI model BLAB/c mice after tail intravenous injection with QDP at various time points (20, 40, $60 \mathrm{~min})$. (B) Fluorescence image of various tissues dissected from control or ALI model mice $3 \mathrm{~h}$ after In Vivo imaging: 1. heart 2. liver 3. spleen 4. lung 5. kidney. (C) Quantification of the relative fluorescence intensity in each organ. (D) Determination of the NE in the serum from control or ALI model mice using QDP. $\quad$ NC represents the normal mice and I refers to the inhibitor Sivelestat. (E) Determination of NE in the bronchoalveolar lavage fluid from control or ALI model mice using QDP. 


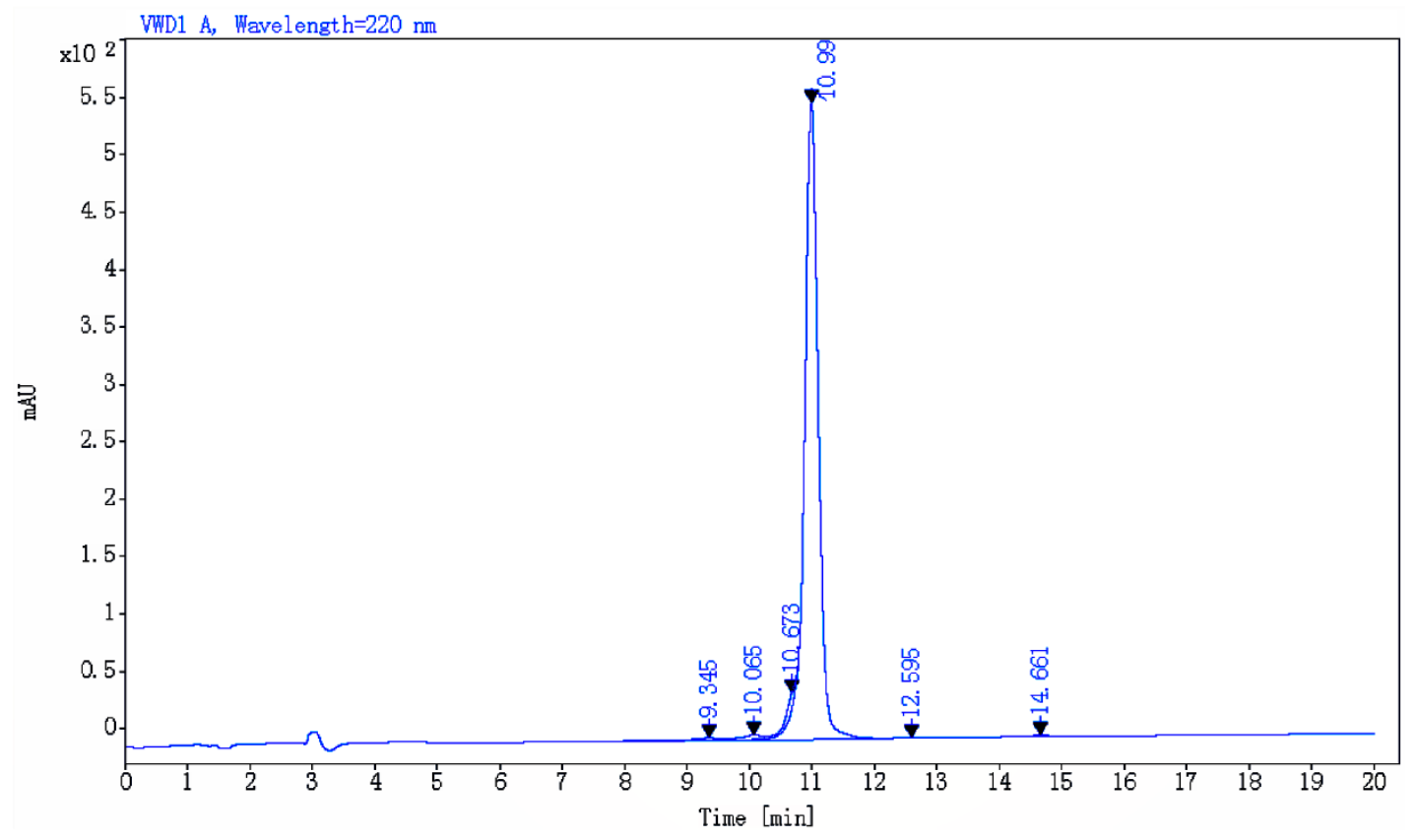

Figure S18. HPLC spectra of sulforhodamine B labeled peptide. The purity of modified peptide is higher than $95 \%$. 


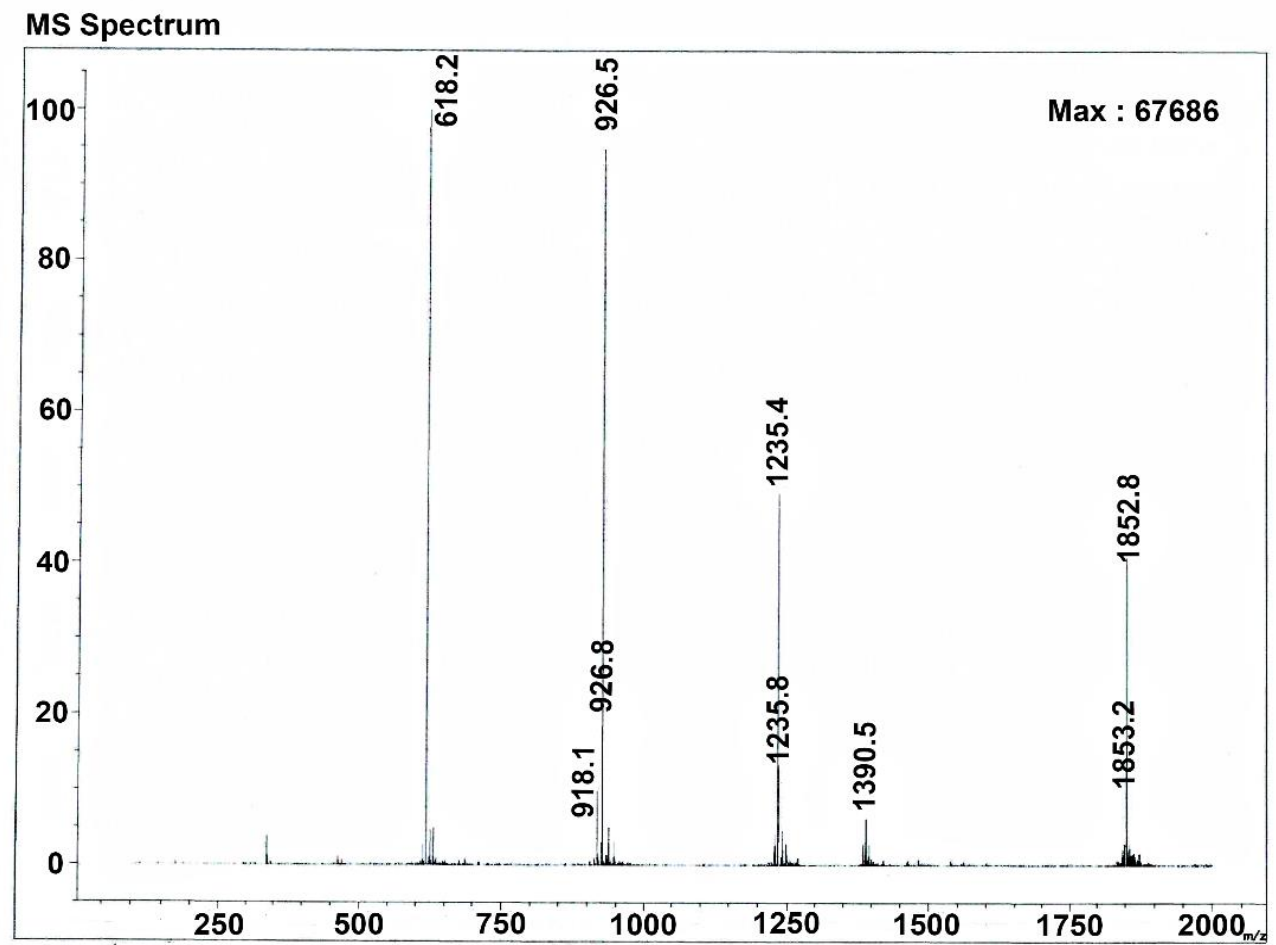

Figure S19. LC-MS spectra of sulforhodamine B labeled peptide.

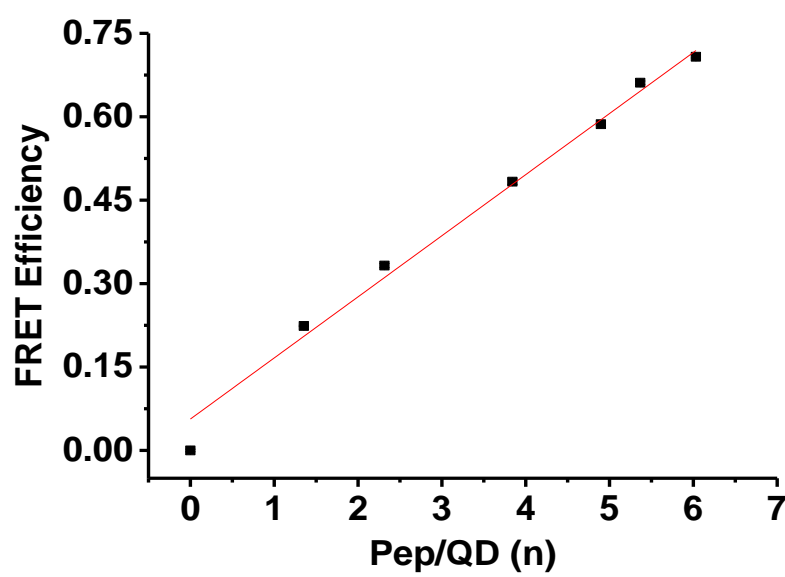

Figure S20. Standard curve of FRET efficiency as a function to the number of dyelabeled peptide. $\mathrm{y}=0.1 \mathrm{x}+0.05$. This curve is important to covert the FRET variation to number of cleaved peptides and initial velocities. 
Table S1. List of quantum yield (QD), calculated overlap integrals $(J)$, calculated Förster distances $\left(R_{0}\right)$ and FRET efficiency for QDP.

\begin{tabular}{c|c|c|c}
\hline $\mathbf{Q}_{\mathbf{D}}(\%)$ & $\boldsymbol{J}\left(\mathbf{M}^{-\mathbf{1}} \mathbf{c m}^{\mathbf{3}}\right)$ & $\boldsymbol{R}_{\mathbf{0}}(\mathbf{n m})$ & $\mathbf{E}(\%)$ \\
\hline 35 & $4.73 \mathrm{E}-13$ & 5.41 & 78.5 \\
\hline
\end{tabular}

Table S2. List of the enzymes used in the substrate specificity study.

\begin{tabular}{c|c|c|c|c}
\hline Enzyme & Company & Organism & $\begin{array}{c}\text { Activity } \\
\text { Provided }\end{array}$ & $\begin{array}{c}\text { Test } \\
\text { Condition }\end{array}$ \\
\hline $\begin{array}{c}\text { Porcine liver } \\
\text { esterase }\end{array}$ & Sigma-Aldrich & porcine & $\geq 150 \mathrm{U} / \mathrm{mg}$ & $\geq 1.5 \mathrm{U} / \mathrm{mL}$ \\
\hline $\begin{array}{c}\text { Chymotrypsin } \\
\text { Trypsin }\end{array}$ & Sigma-Aldrich & human & $\geq 10 \mathrm{U} / \mathrm{mg}$ & $\geq 0.1 \mathrm{U} / \mathrm{mL}$ \\
\hline $\begin{array}{c}\text { Pepsin } \\
\text { Sigma-Aldrich }\end{array}$ & human & $\geq 1000 \mathrm{U} / \mathrm{mg}$ & $\geq 10 \mathrm{U} / \mathrm{mL}$ \\
\hline Sarboxypeptidase & Sigma-Aldrich & yeast & $\geq 50 \mathrm{U} / \mathrm{mg}$ & $\geq 0.5 \mathrm{U} / \mathrm{mL}$ \\
\hline
\end{tabular}




\begin{tabular}{c|c|c|c|c}
\hline BChE & Sigma-Aldrich & equine & $\geq 900 \mathrm{U} / \mathrm{mg}$ & $\geq 9 \mathrm{U} / \mathrm{mL}$ \\
\hline AChE & Sigma-Aldrich & $\begin{array}{c}\text { Electrophorus } \\
\text { electricus }\end{array}$ & $\geq 1000 \mathrm{U} / \mathrm{mg}$ & $\geq 10 \mathrm{U} / \mathrm{mL}$ \\
\hline Carboxylesterase & RD & human & $\geq 6 \mathrm{U} / \mathrm{mg}$ & $\geq 0.06 \mathrm{U} / \mathrm{mL}$ \\
\hline PR3 & Biovision & human & $\geq 2 \mathrm{U} / \mathrm{mg}$ & $\geq 0.02 \mathrm{U} / \mathrm{mL}$ \\
\hline CPG & Biovision & human & $\geq 2 \mathrm{U} / \mathrm{mg}$ & $\geq 0.02 \mathrm{U} / \mathrm{mL}$ \\
\hline HNE & Biovision & human & $\geq 20 \mathrm{U} / \mathrm{mg}$ & $\geq 0.02 \mathrm{U} / \mathrm{mL}$ \\
\hline
\end{tabular}

Table S3. The determination of $K_{\mathrm{m}}$ for HNE against QDP that was prepared at different $\mathrm{D} / \mathrm{A}$ ratios (the ratio of QD with peptide).

\begin{tabular}{c|c|c|c}
\hline $\begin{array}{c}\text { D/A } \\
\text { ratio }\end{array}$ & $\begin{array}{c}\text { The initial } \\
\text { concentration } \\
\text { of QD }\end{array}$ & $\begin{array}{c}\text { The initial } \\
\text { concentration } \\
\text { of peptide }\end{array}$ & $\boldsymbol{K}_{\mathbf{m}}$ \\
\hline $1: 3$ & $1 \mu \mathrm{M}$ & $3 \mu \mathrm{M}$ & $159.32 \mathrm{nM}$ \\
\hline $1: 5$ & $1 \mu \mathrm{M}$ & $5 \mu \mathrm{M}$ & $156.2 \mathrm{nM}$ \\
\hline $1: 7.35$ & $1 \mu \mathrm{M}$ & $7.35 \mu \mathrm{M}$ & $142.3 \mathrm{nM}$ \\
\hline
\end{tabular}


Table S4. IC $_{50}$ values of the reported HNE inhibitors determined by QDP-based assay and other available methods.

\begin{tabular}{c|c|c|c}
\hline Probe & Sivelestat & BAY-678 & References \\
\hline MeOSuc-AAPV-AMC & $\backslash$ & $20 \mathrm{nM}$ & $\begin{array}{c}\text { ChemMedChem, 2015, 10, } \\
1163-1173 .\end{array}$ \\
\hline suc-Ala-Pro-Ala-pNA & $44 \mathrm{nM}$ & $\backslash$ & $\begin{array}{c}\text { Biochemical and Biophysical } \\
\text { Research Communications, } \\
\mathbf{1 9 9 1 , 1 7 7 , 8 1 4 - 8 2 0 .}\end{array}$ \\
\hline QDP & $12.46 \mathrm{nM}$ & $22.77 \mathrm{nM}$ & This Work \\
\hline
\end{tabular}

